\title{
ERRATUM
}

R. R. Klein · P. E. Klein · J. E. Mullet • P. Minx

W. L. Rooney $\cdot$ K. F. Schertz

\section{Fertility restorer locus $R f 1$ of sorghum (Sorghum bicolor L.) encodes a pentatricopeptide repeat protein not present in the colinear region of rice chromosome 12}

Published online: 29 November 2005

(C) Springer-Verlag 2005

\section{Theor Appl Genet (2005) 111:994-1012}

A typesetting error resulted in the article title being rendered without a space between "RfI" and "of".

The online version of the original article can be found at http:// dx.doi.org/10.1007/s00122-005-2011-y

R. R. Klein $(\bowtie) \cdot$ K. F. Schertz

Southern Plains Agriculture Research Center, USDA-ARS,

College Station, TX 77845, USA

E-mail: rklein@tamu.edu

Tel: + 1-979-7774470

Fax: + 1-979-2609333

P. E. Klein

Department of Horticulture and Institute for Plant Genomics and Biotechnology, Texas A\&M University, College Station,

TX 77843-2123, USA

J. E. Mullet

Department of Biochemistry and Biophysics and Institute for

Plant, Genomics and Biotechnology, Texas A\&M University,

College Station, TX 77843-2123, USA

P. Minx

Washington University Genome Sequencing Center, Washington

University School of Medicine, St. Louis, MO 63108, USA

W. L. Rooney

Department of Soil and Crop Science, Texas A\&M University, College Station, TX 77843-2474, USA 